\title{
Significance of Algae in eliminating and deactivating pathological index Organisms in Wastewater Stabilization Pond Systems
}

\author{
Fadwa Ali Hussein Al-Tameemi ${ }^{1}{ }^{*}$,Thura Awad Kadhim ${ }^{2}$ \\ ${ }^{1}$ Lecturer-AL-Yarmouk University College, Iraq. Baghdad . \\ ${ }^{2}$ Lecturer - AL-Yarmouk University College, Iraq. Baghdad .
}

\begin{abstract}
Wastewater stabilization ponds (WSPs) are an economical alternative to conventional wastewater treatment technologies. They are commonly favored by small and rural communities. Due to long hydraulic retention time required by the treatment in these systems, algal activity is often expected during summer season. This study investigated the effects of algal growth on the removal and inactivation of pathogenic indicator organisms in WSP systems. Two predominant algae species (Mougeotia sp. and Nostochopsis sp) that were found in Iraq (Alkhademiyah sewage station in Baghdad) WSP were able to increase both $\mathrm{pH}$ and DO. The highest inactivation rates of both E. coli and total coliforms (TC) were observed at $\mathrm{pH} 10.6$ compared to other $\mathrm{pH}(5.1,8.2,8.4,10.6)$ investigated in the bench-scale experiments. Both high $(20 \mathrm{mg} / \mathrm{L})$ and low DO $(1 \mathrm{mg} / \mathrm{L})$ levels can facilitate the removal and inactivation of both E. coli and TC. Enterococci were significantly reduced at both intermediate $(8.6 \mathrm{mg} / \mathrm{L})$ and high $(20 \mathrm{mg} / \mathrm{L}) \mathrm{DO}$ concentrations. Therefore, the presence of algae can potentially promote the removal of E. coli, TC and Enterococci. Much higher inactivation of E. coli, TC and Enterococci at a higher temperature $\left(20^{\circ} \mathrm{C}\right)$ than at a lower temperature $\left(4^{\circ} \mathrm{C}\right)$ indicates temperature is one the most important removal factor. Two potential/additional indicator organisms (Enterococci and Clostridium perfringens (C. perfringens)) exhibited different inactivation trends than the traditional indicators (E. coli and TC) under the same $\mathrm{pH}$ and DO conditions. C. perfringens were tolerant to all the tested $\mathrm{pH}, \mathrm{DO}$ and temperature conditions. Their resistance to environmental stresses may pose potential health risk. Hence, both Enterococci and C. perfringens could be potentially used as indictor organisms to predict the overall level of pathogens in treatedwastewater.
\end{abstract}

\section{Introduction}

Wastewater stabilization ponds (WSPs) are environmentally sustainable ecosystems that require lower energy inputs and maintenance compared to conventional forms of wastewater treatment $[1,2]$. As such, they have become a popular alternative to conventional technologies, especially in small, rural and remote regions. However, the performance of WSPs is highly dependent on environmental and climatic conditions, hence, the treatment efficiency can

be sensitive to both location and season.

Maturation WSPs, with depth of 1-1.4 m, are designed for disinfection and are often implemented as a tertiary polishing step in wastewater treatment. Over the past two decades, one of the research interests in WSPs has been to understand the mechanisms of pathogen removal in these systems. Previous studies have shown that the main factors contributing to disinfection in WSP systems are: sunlight, $\mathrm{pH}$, dissolved oxygen (DO), temperature, nutrient limitation, water depth, hydraulic retention time, attachment, sedimentation and predation [2-8].

As a result of the long hydraulic retention times associated in these systems, algal activity is often expected during warmer seasons. Consequently, high dissolved oxygen (DO) $(\sim 15 \mathrm{mg} / \mathrm{L})$ and $\mathrm{pH}$ levels $(\sim 9.5)$ are often observed in WSPs containing algae $[1,3,8,9]$. It has been noted in the literature that $\mathrm{pH}$ and $\mathrm{DO}$ are two important factors that can affect the removal and inactivation of pathogenic microorganisms in WSPs $[3,4$, 6]. The presence of algae may influence the various treatments occurring in WSP systems, such as nutrient removal and pathogen removal [8] . Escherichia coli (E. coli), fecal $[10,11]$ coliforms and total coliforms are common indicator organisms that are used to assess the quality of treated wastewater and determine the presence of pathogenic microorganisms [12, 13] Their presence can be a good indication of fecal contamination. However, the limitations associated with the use of traditional fecal indictor organisms have been recognized in the literature; particularly as they can sometimes be limited in their

* Corresponding author: starofiraq2005@yahoo.com ${ }^{1 *}$, 
ability to represent overall pathogen levels [14-16]. A number of potential indicator organisms have been proposed as representative of pathogenic microorganisms in addition to those traditionally employed. Enterococci are one of the potential indicator organisms that have been reported to have better survival rates than fecal coliforms at high $\mathrm{pH}$. In a bench scale study using grab samples of sewage obtained from the Academic Board of Baghdad University treatment plant, [5] observed that Enterococci could survive at $\mathrm{pH}$ levels as high as 11 . Therefore, the use of E. coli, fecal coliforms or total coliforms as indicators may under predict the presence or concentration of Enterococci, especially under high $\mathrm{pH}$ conditions. Clostridium perfringens (C. perfringens), an anaerobic, spore-forming bacteria found in high concentrations in human and animal feces, has been recently used as an additional indicator. Its spore phase is considered highly resistant to environmental conditions, as well as conventional disinfection processes, whereby, [17] found that the inactivation rate of E.coli was one order of magnitude greater than that of $\mathrm{C}$. perfringens. Therefore, it was suggested that rather than E. coli, this microorganism could be used to predict the presence of resistant protozoan and helminthic pathogens such as Cryptosporidium, Giardia and helminth eggs [18-20]; However, a comprehensive understanding of how these indicator organisms would respond to different $\mathrm{pH}, \mathrm{DO}$ and temperature conditions is missing in the literature. The main objective of this study was to investigate the indirect effect of algae on the removal and inactivation of traditional (E. coli and total coliforms) and alternative indicator organisms (Enterococcus and C. perfringens). Bench scale experiments were conducted to examine whether the presence of algae could be responsible for the high $\mathrm{pH}$ and DO levels in WSP systems, then to assess the effect of the high $\mathrm{pH}$ and $\mathrm{DO}$ conditions on the removal and inactivation of both typical and potential indicator organisms.

\section{Material and Methods:}

\subsection{Source of wastewater samples Description of the study area}

Wastewater samples were collected from Alkhademiyah sewage station in Baghdad. extended from southwest of AlKarkh city with their elongation for more than $30 \mathrm{~km}$ passes through vast farmlands, orchards and several residential quarters, followed the figure below (Figure .1). The sewage station treats approximately $1,500 \mathrm{~m}^{3} /$ day of municipal wastewater. The two WSPs have operating depths of $2.61 \mathrm{~m}$ and $4.42 \mathrm{~m} \mathrm{[1].}$ Hydraulic retention times (HRTs) were estimated to be 16 and 8 days [2]. Algal samples were collected, while wastewater samples used for bench $\mathrm{pH}$, DO and temperature tests were collected from the secondary effluent, which had been treated through primary treatment, secondary aeration tanks as well as a secondary clarifier. All the experiments in this research paper are well done in the AL Yarmouk University College laboratories in Baghdad.

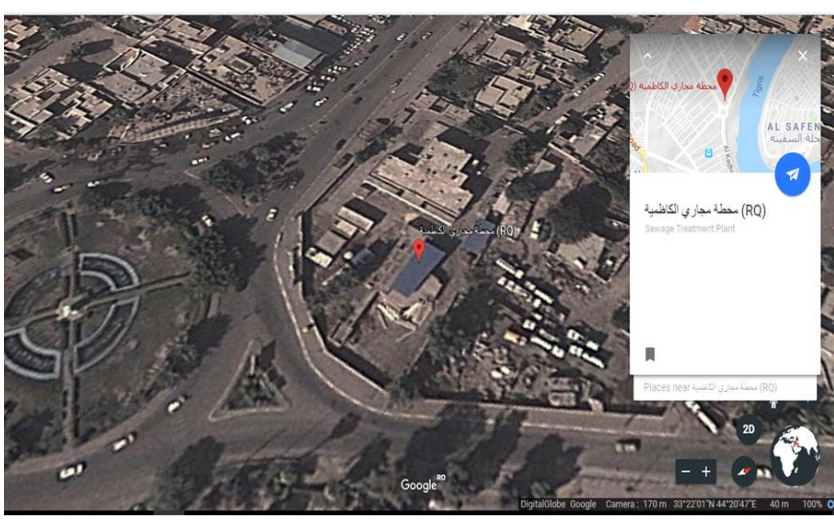

Figure .1. Map of the sampling "Alkhademiyah sewage station in Baghdad".

\subsection{Algae cultivation experiments}

At the Alkhademiyah sewage station in Baghdad, algal blooms are typically observed to start in early June. During the warmer months, from June to September, $\mathrm{pH}$ generally ranged from 9.5 to 11 [3]. Two types of algae were found to be predominant . One was Nostochopsis $s p$., also known as Water Net algae, and tended to float on the water surface. The other one was filamentous aglae, Mougeotia sp. which preferentially attached to the $\mathrm{m}$-acrophytes in the WSP.

A Nikon SMZ25 microscope (Nikon Instruments Inc.) was used to take images of algae. Microscopic images of both algae are shown in Figure .2. These two types of algae were collected on August 17, 2016, and transported to the laboratory in a cooler packed with ice. They were washed five times with autoclaved DI water and cultivated in Bold's Basal Medium (BBM) separately for 6 days at room temperature $\left(\sim 20^{\circ} \mathrm{C}\right)$. Three $500-\mathrm{mL}$ Mason jars, each containing $400 \mathrm{~mL}$ of BBM and $10 \mathrm{~g}$ algae, were prepared for each type of algal. A jar of BBM only (without any algae samples) was also maintained as a control. $\mathrm{pH}$ and $\mathrm{DO}$ levels were monitored daily using a HQ40d portable multi-parameter (Hach, Loveland, CO).

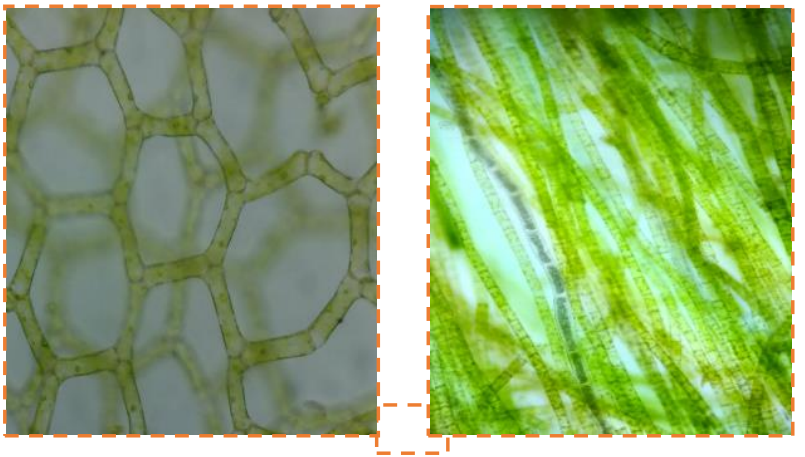

Figure .2. Microscopic images (40X) of two algae, Nostochopsis sp . (a) and Mougeotia sp. (b), isolated from the Alkhademiyah sewage station in Baghdad.

\section{3. $\mathrm{pH}$ experiments}


The purpose of the laboratory $\mathrm{pH}$ experiment was to assess the effect of $\mathrm{pH}$ alone, on the inactivation of indicator organisms. A grab sample was collected from the treatment plant secondary effluent, which is the influent to the first WSP. Seven Liters of the wastewater grab sample was distributed equally into fifteen $500-\mathrm{mL}$ Mason jars. All Mason jars were autoclaved before use. Five different $\mathrm{pH}$ conditions (5.1, 8.2, 8.4, 9.7 and 10.6) were tested in triplicate. $\mathrm{pH}$ was adjusted daily with $0.2 \mathrm{~N}$ $\mathrm{HCl}$ and $0.2 \mathrm{~N} \mathrm{NaOH}$ solutions as required. All the jars were placed in an incubator (Thermo Scientific Refrigerated Incubator) with the temperature of $20{ }^{\circ} \mathrm{C}$ and with a light intensity of 3400 Lux, measured with a REED LM-81LX Compact Light Meter (Reed instruments), and DO was kept at $8.5 \mathrm{mg} / \mathrm{L}$ by bubbling air using aquarium air diffusers. The concentrations of indicator organisms were measured on days 1, 3, 5, 7 and 9.

The indicator organisms selected for this study were $E$. coli, total coliforms, Enterococci and $C$. perfringens. Their concentrations were quantified using the membrane filtration technique (Clesceri et al., 1998), and culture medium (Chromocult Coliform Agar (Merk, Germany), Chromocult Enterococci Agar (Merk, Germany), and mCP Agar base for microbiology (Mil lliporeSigma, Canada) (Reinoso et al., 2011; Mosteo et al., 2011; Ouali et al, 2014). Plate counting was performed after a 24-hour incubation period at $37^{\circ} \mathrm{C}$ for $E$. coli, total coliforms and Enterococci, and a 48 -hour anaerobic incubation at $44^{\circ} \mathrm{C}$ for $C$. perfringens in an anaerobic jar (Merk, Germany). In this study, the "inactivation" and "removal" of indicator organisms referred to the disappearance of culturable colonies. The detection limit was $1 \mathrm{CFU} / 100$ $\mathrm{mL}$. If no culturable organisms were found in $100 \mathrm{~mL}$ sample, the concentration was noted as zero.

\subsection{DO experiments}

Three DO levels of $1,8.5$ and $20 \mathrm{mg} / \mathrm{L}$ were investigated to simulate low, intermediate (control) and high DO concentrations. $\mathrm{pH}$ and temperature were maintained at 7 and $20^{\circ} \mathrm{C}$, respectively. A secondary effluent sample was collected from the wastewater treatment plant. Three replicates of each DO condition were prepared. A sample volume of $400 \mathrm{~mL}$ was transferred into each of nine 500$\mathrm{mL}$ Mason jars. Low, intermediate and high DO conditions were maintained by constantly bubbling $\mathrm{N}_{2}$, air and $\mathrm{O}_{2}$ using aquarium air diffusers, respectively. The concentrations of indicator organisms were measured on days $1,3,7,9,11$ and 13 .

\subsection{Temperature experiments}

The inactivation and removal of indicator organisms were measured at room temperature $\left(20^{\circ} \mathrm{C}\right)$ to simulate warmer season, and at an incubator temperature of $4^{\circ} \mathrm{C}$ to simulate colder season. A grab sample from Alkhademiyah sewage station in Baghdad effluent was obtained. Sample volume of $400 \mathrm{~mL}$ was used in each Mason jar. Both temperature condition experiments were conducted in triplicate. $\mathrm{pH}$ and DO were kept at 7 and 8.6 $\mathrm{mg} / \mathrm{L}$, respectively. The concentrations of indicator organisms were measured on days $1,3,5,8,10,13$ and 15.

\subsection{Statistical analysis}

t-test is most commonly applied when the test statistic would follow a normal distribution. The t-test was used to determine if two sets of data are significantly different from each other for different $\mathrm{pH}, \mathrm{DO}$ and temperature conditions.

\section{Results and Discussion}

Over a monitoring period of 6 days, $\mathrm{pH}$ and DO were noted to increase from $5.2 \pm 0.1$ to $8.1 \pm 0.3$, and from $6.1 \pm 0.1$ to $9.1 \pm 0.2$, respectively, in Mougeotia $s p$. jars (Figure.3). Similarly, in the Nostochopsis sp . jars, $\mathrm{pH}$ increased from $6.0 \pm 0.1$ to $9.0 \pm 0.3$, and DO from $6.2 \pm 0.1$ to $7.5 \pm 0.4$ (Figure .4). In the control Mason jar, $\mathrm{pH}$ varied between 5.9 and 6.2, while DO fluctuated between 5.8 and 6.2 (Figure .5). The increases in both $\mathrm{pH}$ and DO were considered significant compared to the control $(p<0.05)$. There were significant increases in both $\mathrm{pH}$ $(p<0.05)$ and DO $(p<0.05)$ in both Nostochopsis sp. and Mougeotia sp. jars. This experiment confirmed that the two predominant algal species found were likely responsible for the high $\mathrm{pH}$ and $\mathrm{DO}$ levels observed.

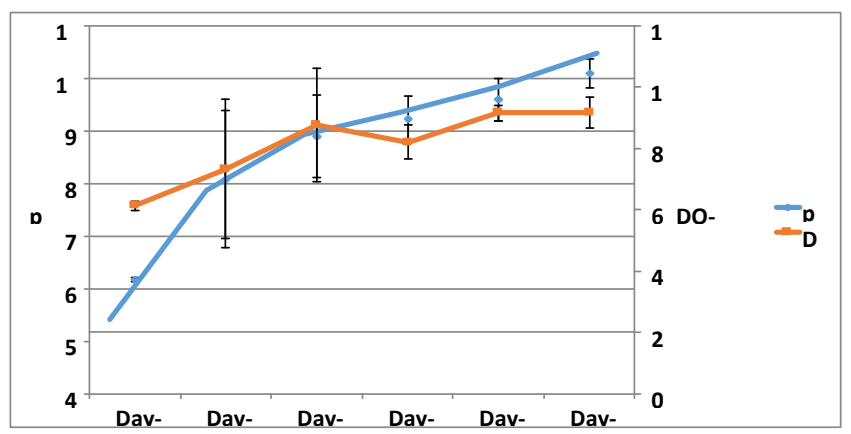

Figure .3. Changes in $\mathrm{pH}$ and DO over a 6-day period in the Mason jars containing Mougeotia $s p$. and BBM. Average $\mathrm{pH}$ and DO levels presented in this figure were calculated from three replicate jars. Error bars represent standard deviation.

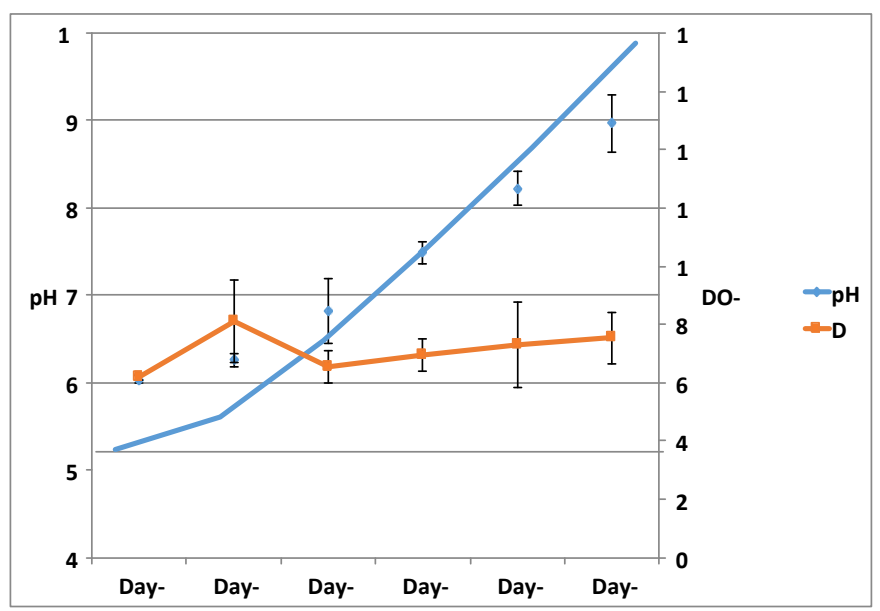


Figure.4. Changes in $\mathrm{pH}$ and DO over a 6-day monitoring period in the Mason jars containing BBM and Nostochopsis $s p$. Average $\mathrm{pH}$ and DO levels presented in this figure were calculated from three replicate Mason jars. Error bars represent standard deviation.

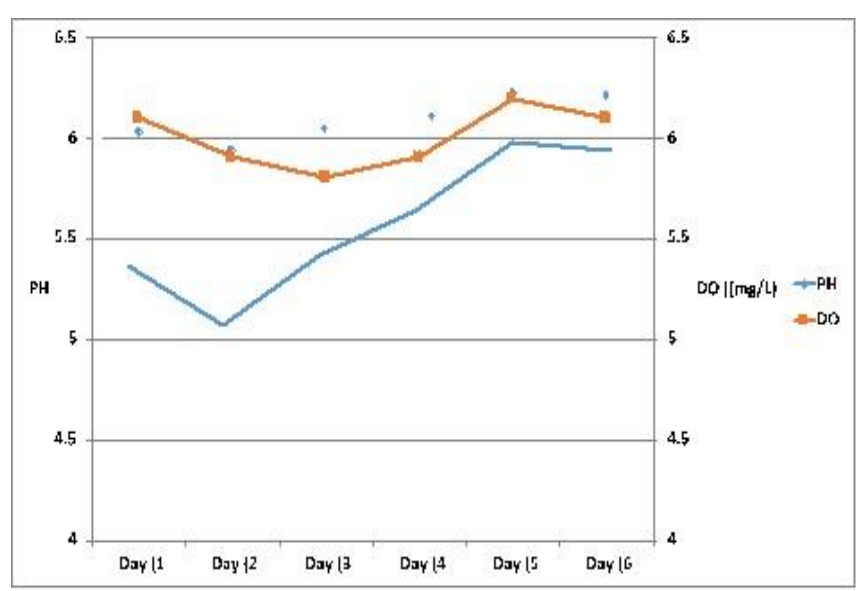

Figure .5. Changes in $\mathrm{pH}$ and $\mathrm{DO}$ over a monitoring period of 6 days in the control jar containing BBM alone.

The inactivation of four indicator organisms (E. coli, total coliforms, Enterococci and C. perfringens) was tested under five $\mathrm{pH}$ conditions, $\mathrm{pH} 5.1,9.7,8.4,8.2$, and 10.6. The initial concentrations of $E$. coli, total coliforms, Enterococci and $C$. perfringens in the secondary effluent were $3.16,4.75,3.44$ and $3.17 \log \mathrm{CFU} / 100 \mathrm{ml}$, respectively. The original sample with a $\mathrm{pH}$ of 8 was used as a control in this study. Inactivation rates of indicator organisms were estimated by the first order rates constants, $k$, which was calculated by using Equation (1) $[4,5]$ :

$$
\operatorname{In}\left(\frac{c_{t}}{c_{0}}\right)=-K t
$$

where $C_{0}$ is the initial concentration $(\mathrm{CFU} / 100 \mathrm{~mL})$, and $C_{\mathrm{t}}$ represents the concentration $(\mathrm{CFU} / 100 \mathrm{~mL})$ at time, $t$. The inactivation of the selected indicator organisms throughout the 9 days of exposure to different $\mathrm{pH}$ levels is compared in Figure .6. Table .1 summarized the inactivation rates of the four indicator organisms under the different $\mathrm{pH}$ conditions. First order inactivation rate constants for $E$. coli ranged from 0.11 day $^{-1}$ at $\mathrm{pH} 8$ to 0.19 day $^{-1}$ at $\mathrm{pH}$ 10.5. Inactivation rates for total coliforms varied between 0.08 day $^{-1}$ at $\mathrm{pH} 8$ and $\mathrm{pH} 8.4$ and $0.12 \mathrm{day}^{-1}$ at $\mathrm{pH} 10.5$. In general, the inactivation rates of both $E$. coli and total coliforms increased with an increase in $\mathrm{pH}$. However, no significant differences $(\mathrm{p}>0.05)$ between the tested $\mathrm{pH}$ were found. These observations were consistent with the studies done in the literature. In a study by [6] , it was found that $\mathrm{pH}$ of 8 and 8.8 (tested $\mathrm{pH}$ include 6.6, 7.3, 8 and 8.8) inhibited the survival of $E$. coli. [7] found that the inactivation rate of $E$. coli increased when $\mathrm{pH}$ was above 8.5 . A study by [8] and [1] also reported that no significant difference in decay rates of fecal coliforms at $\mathrm{pH}$ levels of 5, 7,9 and 10 , and under both sunlight and dark conditions. In a previous study, Liu et al. (2015) reported a strong and negative correlation between $\mathrm{pH}$ and $E$. coli concentrations over a monitoring period of 5 years at the Alkhademiyah sewage station - Baghdad and during this monitoring period, E. coli concentrations tended to increase when $\mathrm{pH}$ decreased below 8. At $\mathrm{pH} 10.6$, it was noted that there was a sharp decay with the inactivation rate of $0.30 \mathrm{~d}^{-1}$ for $E$. coli and $0.23 \mathrm{~d}^{-1}$ for total coliforms during first 4 days.

Table .1. Inactivation rates of four indicator organisms at different $\mathrm{pH}$ levels. (DO was at $8.6 \mathrm{mg} / \mathrm{L}$ and temperature was at $20^{\circ} \mathrm{C}$ )

\begin{tabular}{lllll}
\hline & E. coli, d-1 Total coliforms, d-1 & $\begin{array}{l}\text { Enterococci, } \\
\text { d-1 }\end{array}$ & $\begin{array}{l}\text { C. perfringens, } \\
\text { d-1 }\end{array}$ \\
\hline pH 8.2 & 0.12 & 0.05 & 0.19 & -0.01 \\
\hline pH 8.4 & 0.13 & 0.07 & 0.21 & -0.01 \\
\hline pH 9.7 & 0.14 & 0.08 & 0.10 & -0.01 \\
\hline pH 10.6 & 0.18 & 0.14 & 0.08 & -0.01 \\
\hline pH 5.1 & 0.16 & 0.12 & $*$ & -0.01
\end{tabular}

*Final concentration was below detection limit of 1 CFU/100mL.

Unlike E. coli and total coliforms, a higher removal and inactivation of Enterococci was observed at $\mathrm{pH} 5.1$ and $\mathrm{pH}$ 8.4. There were no Enterococci detected after day 3 at $\mathrm{pH}$ 5.1. This observation could challenge the use of $E$. coli and total coliforms to represent pathogenic

Enterococci as these organisms showed different responses to various $\mathrm{pH}$ conditions. Inactivation of $E$. coli increased with increasing $\mathrm{pH}$ while in contrast, Enterococci was noted to exhibit similar rates of inactivation at all $\mathrm{pH}$ levels [7-9] also reported that low $\mathrm{pH}$ ( $\mathrm{pH} 4$ and 5) had a more bactericidal effect on Enterococci in domestic wastewater than alkaline conditions. Spore forming bacteria, C. perfringens, showed resistance to all the $\mathrm{pH}$ levels investigated during the test period. They may require a longer period of time to be inactivated or $\mathrm{pH}$ is not a significant removal mechanism for $C$. perfringens.

The effects of different DO concentrations on the removal and inactivation of indicator organisms were also investigated in this study. Table .2 presents the inactivation rates of the four indicator organisms at low, intermediate and high DO levels. Figure .7 shows the concentrations of E. coli, total coliforms, Enterococci and $C$. perfringens at different DO levels over the 13-day testing period. The highest inactivation rates for both $E$. coli and total coliforms were observed at the high DO concentration of $20 \mathrm{mg} / \mathrm{L}$ (Figure .7 (a) and (b)). Among the selected indicator organisms, E. coli, total coliforms and Enterococci are facultative anaerobes, while $C$. perfringens are obligate anaerobes. Facultative anaerobes can metabolize either aerobically or anaerobically; however these organisms prefer aerobic conditions as aerobic respiration generates more adenosine triphosphate (ATP) than either fermentation or anaerobic respiration. This could explain why comparatively low inactivation rates were generally found under 
intermediate DO condition of $8.5 \mathrm{mg} / \mathrm{L}$ for both $E$. coli and total coliforms, while high DO concentrations could promote the removal of these two microorganisms. However, no significant differences $(p>0.05)$ between the DO concentrations were found. David-Colley et al. (1995) also observed a synergistic increase in inactivation of $E$. coli when both DO and $\mathrm{pH}$ increased. The light inactivation of E. coli and Enterococci have been reported to increase with increasing DO concentrations [7, $8,10]$.
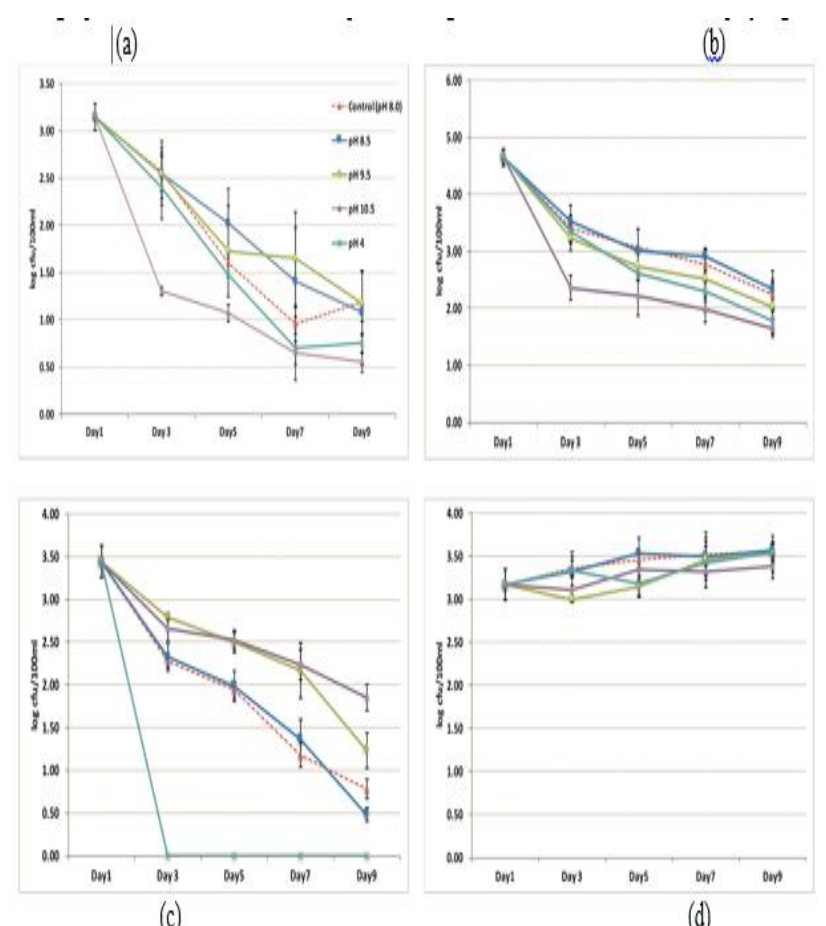

Figure .6. Inactivation and removal of E. coli (a), total coliforms (b), Enterococci (c) and C. perfringens (d) in the secondary effluent wastewater collected from the Alkhademiyah sewage station in Baghdad governorate, over a 9-day period during exposure to $\mathrm{pH}$ levels of 5.1, $8.4,8.2,9.7$ and 10.6 .

For the removal and inactivation of Enterococci, a higher inactivation rate was found at high and intermediate DO concentrations. The Enterococci species obtained from the secondary effluent appeared to exhibit a higher growth rate at lower DO concentrations. Moreover, a significant difference was found between low DO and high DO $(p=0.004)$. As such, this would suggest that when DO was enhanced by algal photosynthesis during warm season, it could facilitate the inactivation of Enterococci. Although $C$. perfringens are obligate anaerobes, and oxygen can be considered toxic to them, they showed a minimum inactivation rate of 0.01 day $^{-1}$ at high DO concentration over the monitoring period of 13 days. This again shows the resistance to environmental stresses of $C$. perfringens.

Table.2. Inactivation rates of four indicator organisms at low $(1 \mathrm{mg} / \mathrm{L})$, intermediate $(8.6 \mathrm{mg} / \mathrm{L})$ and high DO $(20 \mathrm{mg} / \mathrm{L})$ levels $(\mathrm{pH}$ was at 7 and temperature was at $\left.20^{\circ} \mathrm{C}\right)$

\begin{tabular}{lcccc} 
& $\begin{array}{l}\text { E. coli, Total } \\
\text { day }^{-1}\end{array}$ & $\begin{array}{c}\text { coliforms, Enterococci, } \\
\text { day }^{-1}\end{array}$ & $\begin{array}{l}\text { C. perfringens, } \\
\text { day }^{-1}\end{array}$ \\
\hline $\begin{array}{l}\text { Control } \\
(8.6 \mathrm{mg} / \mathrm{L})\end{array}$ & 0.05 & 0.02 & $*$ & -0.01 \\
\hline High D0 & $*$ & $*$ & $*$ & 0.01 \\
$(20 \mathrm{mg} / \mathrm{L})$ & & & & \\
\hline $\begin{array}{l}\text { Low DO } \\
(1 \mathrm{mg} / \mathrm{L})\end{array}$ & $*$ & $*$ & 0.01 & 0.00 \\
\hline
\end{tabular}

*Final concentration was below detection limit of $1 \mathrm{CFU} / 100 \mathrm{~mL}$.
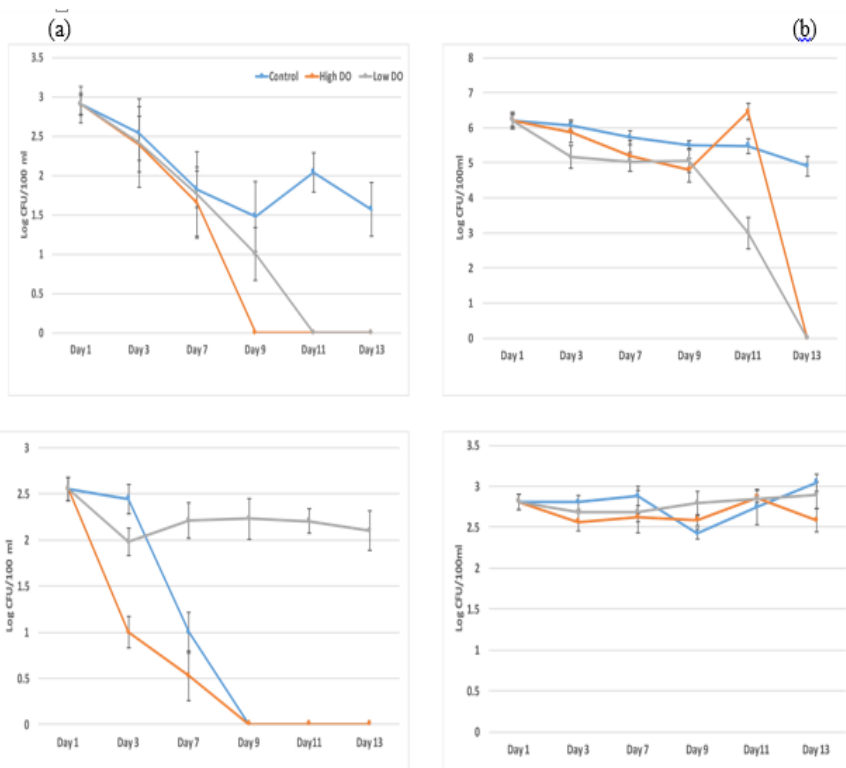

(c)

(d)

Figure .7. Inactivation and removal of E. coli (a), total coliforms (b), Enterococci (c) and C. perfringens (d) in the secondary effluent wastewater collected from the Alkhademiyah sewage station in Baghdad governorate over a 13-day period when they were exposed to low, intermediate and high DO levels. Temperature were maintained at $20^{\circ} \mathrm{C}$.

Two temperatures $\left(4^{\circ} \mathrm{C}\right.$ and $\left.20^{\circ} \mathrm{C}\right)$ were selected to simulate the cold and warm seasons, and to assess their effects on the removal and inactivation of indicator organisms. Figure .8 shows the concentrations of $E$. coli (a), total coliforms (b), Enterococci (c) and $C$. perfringens $(\mathrm{d})$ under warm $\left(\mathrm{T}=20^{\circ} \mathrm{C}\right)$ and cold $\left(\mathrm{T}=4{ }^{\circ} \mathrm{C}\right)$ temperatures over a monitoring period of 15 days.

The inactivation rates of $E$. coli were -0.02 day $^{-1}$ at $4{ }^{\circ} \mathrm{C}$ and 0.11 day $^{-1}$ at $20^{\circ} \mathrm{C}$, while for total coliforms, the inactivation rates ranged from $-0.01 \mathrm{day}^{-1}$ and $0.03 \mathrm{day}^{-1}$, respectively. There was no Enterococci colony detected on day 12 under the $20^{\circ} \mathrm{C}$ condition and the inactivation rate for the first 10 days was 0.23 day $^{-1}$. Meanwhile, the inactivation rate of Enterococci at $4^{\circ} \mathrm{C}$ was 0.05 day $^{-1}$. The concentrations of $E$. coli, total coliforms and Enterococci were generally significantly reduced at $20^{\circ} \mathrm{C}$ compared to at $4^{\circ} \mathrm{C}(p<0.05)$. This finding agrees with observation made by several researchers as they have reported increased removal efficiencies of fecal coliforms 
at higher temperatures [26]; Pearson [10, 25, 27] . In a study by [24], fecal coliforms were reduced by $98.95 \%$ during the warmer seasons and by $94.91 \%$ during the cold seasons in a WSP system, operating in Marrakesh, Morocco. This system consisted of an anaerobic and an aerobic pond in series. They also found that when temperature was increased from $8^{\circ} \mathrm{C}$ to $23^{\circ} \mathrm{C}$, the removal rate of $E$. coli also increased. For $C$. perfringens removal in this study, they were generally tolerant to the wide range of temperature during a 15-day test period.

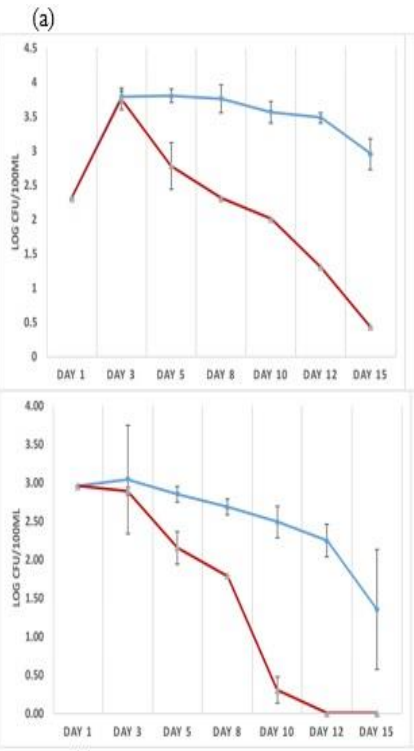

(c)

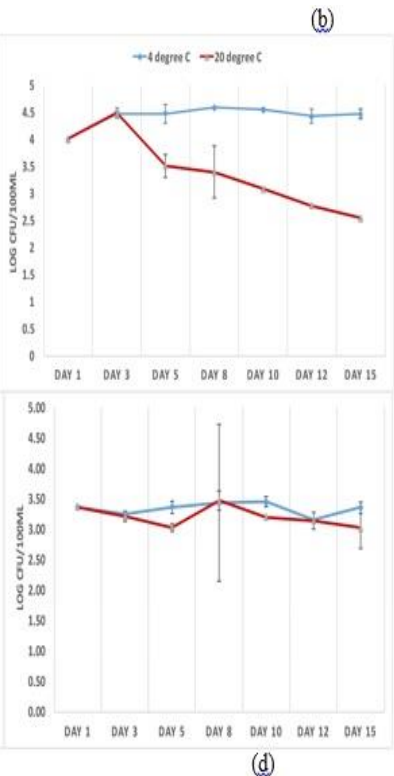

(d)
Figure .8. Inactivation and removal of E. coli (a), total coliforms (b), Enterococci (c) and C. perfringens (d) in the secondary effluent wastewater collected from the Alkhademiyah sewage station in Baghdad governorate over a 15-day period when they were exposed warm $\left(\mathrm{T}=20^{\circ} \mathrm{C}\right)$ and cold $\left(\mathrm{T}=4^{\circ} \mathrm{C}\right)$ temperatures.

\section{Conclusion}

This paper investigated the effects of $\mathrm{pH}(5.1,8.2,8.4$, 9.7 and 10.6), DO (1, 8.5 and $20 \mathrm{mg} / \mathrm{L})$ and temperature $\left(4{ }^{\circ} \mathrm{C}\right.$ and $20^{\circ} \mathrm{C}$ ) on the inactivation and removal of four indicator organisms (two traditional ones and two potential ones). Both algae (Mougeotia $s p$. and Nostochopsis sp.) that were collected from the Alkhademiyah sewage station in Baghdad WSP were noted to increase both $\mathrm{pH}$ and $\mathrm{DO}$ when cultivated under laboratory conditions. Their presence is believed to contribute to the high $\mathrm{pH}$ and DO levels in the WSP system.

The inactivation of $E$. coli and total coliforms were found to increase with increasing in $\mathrm{pH}$. The highest inactivation rates were observed at $\mathrm{pH}$ 10.6. Intermediate DO level appeared to support the survival of both E. coli and total coliforms, while both high and low DO levels could facilitate their removal and inactivation. Enterococci were significantly reduced at both intermediate and high DO concentrations. This would suggest that the presence of algae leading to high DO concentrations could potentially promote the removal of E. coli, total coliforms and Enterococci.
Two additional indicator organisms (Enterococci and C. perfringens) showed different inactivation trends compared to traditional indicator organisms. $C$. perfringens were tolerant to the $\mathrm{pH}, \mathrm{DO}$ and temperature ranges investigated. This would suggest that E. coli and total coliforms are limited in their ability to represent the presence and concentration of Enterococci and $C$. perfringens. This finding supports the literature where they have been suggested to be potential indicator organisms of pathogens in addition to E. coli, fecal coliforms and total coliforms.

Disinfection efficiencies should be expected to exhibit seasonal variations in WSP systems operated in temperate climates. Higher removal efficiencies of indicator organisms would be expected during the warmer seasons, which will continue to pose challenges to winter operation unless some engineered operational modifications can be adapted that will facilitate their retention and removal under colder conditions, which would normally be expected to offer more limited inactivation efficiencies.

\section{Acknowledgment}

The authors would like to express their appreciation for the support of the sponsors from paper 2018 6th International Conference on Environment Pollution and Prevention (ICEPP 2018) Brisbane, Australia ,December 6-8, 2018. Our gratitude also goes to the editor and anonymous reviewers who reviewed this paper.

\section{References}

1. N. Bolton, N. Cromar, P. Hallsworth, and H. Fallowfield, "A review of the factors affecting sunlight inactivation of micro-organisms in waste stabilisation ponds: preliminary results for enterococci," Water Science and Technology, vol. 61, p. $885,2010$.

2. K. Kadir and K. L. Nelson, "Sunlight mediated inactivation mechanisms of Enterococcus faecalis and Escherichia coli in clear water versus waste stabilization pond water," Water research, vol. 50, pp. 307-317, 2014.

3. T. P. Curtis, D. D. Mara, and S. A. Silva, "Influence of $\mathrm{pH}$, oxygen, and humic substances on ability of sunlight to damage fecal coliforms in waste stabilization pond water," Applied and environmental microbiology, vol. 58, pp. 1335-1343, 1992.

4. R. Davies-Colley, A. Donnison, D. Speed, C. Ross, and J. Nagels, "Inactivation of faecal indicator micro-organisms in waste stabilisation ponds: interactions of environmental factors with sunlight," Water research, vol. 33, pp. 1220-1230, 1999.

5. E. Awuah, Pathogen removal mechanisms in macrophyte and algal waste stabilization ponds, 2006. 
6. E. Ansa, H. Lubberding, J. Ampofo, G. Amegbe, and H. Gijzen, "Attachment of faecal coliform and macro-invertebrate activity in the removal of faecal coliform in domestic wastewater treatment pond systems," Ecological engineering, vol. 42, pp. 35-41, 2012.

7. D. Moumouni, H. Andrianisa, Y. Konaté, A. Ndiaye, and A. Maïga, "Inactivation of Escherichia coli in a baffled pond with attached growth: treating anaerobic effluent under the Sahelian climate," Environmental technology, vol. 37, pp. 1054-1064, 2016.

8. J. Wallace, P. Champagne, and G. Hall, "Multivariate statistical analysis of water chemistry conditions in three wastewater stabilization ponds with algae blooms and $\mathrm{pH}$ fluctuations," Water research, vol. 96, pp. 155-165, 2016.

9. L. Liu, G. Hall, and P. Champagne, "Effects of environmental factors on the disinfection performance of a wastewater stabilization pond operated in a temperate climate," Water, vol. 8, p. 5, 2015.

10. M. A. H. Saeed, M. H. Lak, and J. J. Toma, "Environmental and biological study of Arab-Kand waste water channel in Erbil governorate Kurdistan region-Iraq," Tikrit Journal of Pure Science, vol. 15, pp. 91-100, 2010.

11. Y. A. Shekha, "The effect of Erbil city wastewater discharge on water quality of Greater Zab river, and the risks of irrigation," PhD, university of Baghdad, 2008.

12. R. Jamieson, R. Gordon, D. Joy, and H. Lee, "Assessing microbial pollution of rural surface waters: A review of current watershed scale modeling approaches," Agricultural water management, vol. 70, pp. 1-17, 2004.

13. L. Boutilier, R. Jamieson, R. Gordon, C. Lake, and W. Hart, "Adsorption, sedimentation, and inactivation of E. coli within wastewater treatment wetlands," Water research, vol. 43, pp. 4370-4380, 2009.

14. W. Burkhardt III, K. R. Calci, W. D. Watkins, S. R. Rippey, and S. J. Chirtel, "Inactivation of indicator microorganisms in estuarine waters," Water Research, vol. 34, pp. 2207-2214, 2000.

15. Y. Len, C. Wen-Shi, and L. Mong-Na, "Natural disinfection of wastewater in marine outfields," Water Res, vol. 34, pp. 743-750, 2000.

16. P. Molleda, I. Blanco, G. Ansola, and E. de Luis, "Removal of wastewater pathogen indicators in a constructed wetland in Leon, Spain," Ecological Engineering, vol. 33, pp. 252-257, 2008.

17. P. S. Dunlop, T. A. McMurray, J. W. Hamilton, and J. A. Byrne, "Photocatalytic inactivation of Clostridium perfringens spores on $\mathrm{TiO} 2$ electrodes," Journal of Photochemistry and Photobiology A: Chemistry, vol. 196, pp. 113-119, 2008.
18. N. Abreu-Acosta and L. Vera, "Occurrence and removal of parasites, enteric bacteria and faecal contamination indicators in wastewater natural reclamation systems in Tenerife-Canary Islands, Spain," Ecological engineering, vol. 37, pp. 496-503, 2011.

19. M. Lanao, M. Ormad, P. Goñi, N. Miguel, R. Mosteo, and J. Ovelleiro, "Inactivation of Clostridium perfringens spores and vegetative cells by photolysis and $\mathrm{TiO} 2$ photocatalysis with $\mathrm{H} 2 \mathrm{O} 2$," Solar energy, vol. 84, pp. 703-709, 2010.

20. R. Mosteo, M. Ormad, P. Goñi, J. Rodríguez-Chueca, A. García, and A. Clavel, "Identification of pathogen bacteria and protozoa in treated urban wastewaters discharged in the Ebro River (Spain): water reuse possibilities," Water Science and Technology, vol. 68, pp. 575-583, 2013.

21. Y. O. M. Al-Barzingy, J. J. Toma, and Y. A. Shekha, "Algal Survey in Wastewater Channel of Erbil City, Iraq," Diyala Journal For Pure Science, vol. 12, pp. 39-57, 2016.

22. Y. O. M. Al-Barzingy, N. H. Haydar, and Y. A. Shekha, "The effect of wastewater disposal on the water quality and phytoplankton in Erbil wastewater channel," Baghdad Science Journal, vol. 7, pp. 984993, 2010

23. R. H. Kadlec and S. Wallace, Treatment wetlands: CRC press, 2008.

24. N.-E. Mezrioui and B. Oudra, "Dynamics of picoplankton and microplankton flora in the experimental wastewater stabilization ponds in the arid region of Marrakech, Morocco and cyanobacteria effect on Escherichia coli and Vibrio cholerae survival," in Wastewater treatment with algae, ed: Springer, 1998, pp. 165-188.

25. A. Ouali, H. Jupsin, A. Ghrabi, and J. Vasel, "Removal kinetic of Escherichia coli and enterococci in a laboratory pilot scale wastewater maturation pond," Water Science and Technology, vol. 69, pp. 755-759, 2014.

26. C. Polprasert, M. Dissanayake, and N. Thanh, "Bacterial die-off kinetics in waste stabilization ponds," Journal (Water Pollution Control Federation), pp. 285-296, 1983.

27. R. Reinoso, S. Blanco, L. A. Torres-Villamizar, and E. Bécares, "Mechanisms for parasites removal in a waste stabilisation pond," Microbial ecology, vol. 61, pp. 684-692, 2011. 